\title{
Commentary: Ownership Neutrality and Practical Complications
}

\section{Citation}

Stephen E. Shay, Commentary: Ownership Neutrality and Practical Complications, 62 Tax L. Rev. 317 (2009).

\section{Published Version}

http://heinonline.org/HOL/Page?handle=hein.journals/taxlr62\&g_sent=1\&id=321

\section{Permanent link}

http://nrs.harvard.edu/urn-3:HUL.InstRepos:23936125

\section{Terms of Use}

This article was downloaded from Harvard University's DASH repository, and is made available under the terms and conditions applicable to Other Posted Material, as set forth at http:// nrs.harvard.edu/urn-3:HUL.InstRepos:dash.current.terms-of-use\#LAA

\section{Share Your Story}

The Harvard community has made this article openly available.

Please share how this access benefits you. Submit a story.

Accessibility 


\title{
Commentary \\ Ownership Neutrality and Practical Complications
}

\author{
STEPHEN E. SHAY*
}

\section{INTRODUCTION}

In "Reconsidering the Taxation of Foreign Income," Jim Hines analyzes the consequences of taxing, as opposed to exempting, active foreign business income by comparing the expected effects on capital ownership of a "pure" worldwide income taxation system with the effects on capital ownership of a "pure" territorial taxation regime. ${ }^{1}$ Consistent with his earlier work, Hines asserts that a capital ownership neutrality analysis supports exempting foreign active business income from home country residence taxation and points to global welfare losses from taxing income on a worldwide basis with a credit for foreign taxes.

As he has previously, Hines sets up his discussion of capital ownership neutrality by criticizing the "older wisdom" of international tax policy that established a "tension between policies that maximize national welfare- $\mathrm{NN}$-and policies that maximize global welfareCEN."2 According to Hines, perhaps the most critical of the assump-

* Partner, Ropes \& Gray LLP. The views expressed in this comment are the author's personal views and are not intended to represent the views of Ropes \& Gray LLP or its clients.

1 James R. Hines Jr., Reconsidering the Taxation of Foreign Income, 62 Tax L. Rev. 269 (2009). As is well known to the readers of U.S. international tax policy literature, Hines, working with his frequent co-author Mihir Desai, has introduced the question of ownership distortion to the debate regarding the efficiency consequences of international tax policy. Mihir A. Desai \& James R. Hines Jr., Old Rules and New Realities: Corporate Tax Policy in a Global Setting, 57 Nat'l Tax J. 937 (2004); Mihir A. Desai \& James R. Hines Jr., Evaluating International Tax Reform, 56 Nat'l Tax J. 487 (2003); Mihir A. Desai, New Foundations for Taxing Multinational Corporations, Taxes, Mar. 2004, at 39; see also J. Clifton Fleming Jr. \& Robert J. Peroni, Exploring the Contours of a Proposed U.S. Exemption (Territorial) System, 109 Tax Notes 1557 (Dec. 19, 2005).

2 Hines, note 1 , at 273 . Desai provides the following description of these neutrality standards:

CEN is the doctrine that the return to capital should be taxed at the same total rate regardless of the location in which it is earned, thereby advancing global welfare. ... NN narrows the focus to the returns to the home country by excluding the consideration of foreign taxes paid. As a consequence, deductions for foreign taxes paid are recommended under such a system. 
tions underlying the traditional investment location neutrality framework is that "home country taxation does not directly or indirectly affect foreign firms." 3 Hines argues that if greater investment abroad triggers greater investment by foreign firms in the residence country, "[t]he NN implication that home countries maximize their own welfare by subjecting foreign income to taxation with only deductions for foreign income tax payments then no longer follows." 4 If the productivity of an investment depends on its ownership (without regard to the location of the investment) and home and foreign firms compete for ownership of capital around the world, then taxation of foreign income (with a credit for foreign tax) does not necessarily contribute to production efficiency. Instead, Hines argues, different home country taxation resulting from worldwide taxation distorts optimal asset ownership and results in a global welfare loss. ${ }^{5}$ In the absence of a global adoption of worldwide taxation, Hines concludes that under an ownership neutrality analysis, exemption of foreign income advances national welfare. ${ }^{6}$

In considering the problem of allocation of expenses, Hines argues that, to assure ownership neutrality, it is not enough to exempt foreign net income. ${ }^{7}$ In addition, "general expenses," such as interest and general administrative overhead, should "not be allocated at all [between domestic and foreign income], but instead traced to their uses."

Hines briefly considers the implications of certain practical complications, including transfer pricing and the difficulty of sourcing income, for his analysis. ${ }^{9}$ Hines suggests that allowing transfer pricing enforcement concerns to affect the policy prescription would have "a strong element of the transfer pricing tail wagging the tax system dog." 10 In response to fairness questions raised by favorable treatment for foreign income, Hines argues that equity considerations in fact support a special regime for foreign income. ${ }^{11}$

Desai, note 1 , at 45 .

3 Hines, note 1 , at 275 . The other three assumptions are: (1) the residence country efficiency goal (in the case of $\mathrm{NN}$ ) is maximizing tax revenue and after-tax worldwide profits of firms subject to residence taxation, (2) tax policies of other countries are unaffected by changes in residence country tax policies, and (3) tax rate differences are unrelated to the differences in the benefits that host countries receive from incoming foreign investment. Id.

4 Id.

5 Id. at 276.

6 Id. at $276-77$.

7 Id. at 283.

8 Id.

9 Id. at 295-97.

10 Id. at 296-97.

11 Id. at 292-94. 
This Commentary first considers the significance of ownership neutrality for economic efficiency based on observations of ownership arrangements in today's marketplace. It next probes certain premises of Hines' argument, including whether substituting foreign-owned for domestic-owned investment results in equal tax revenue from the investment and whether asset ownership is meaningfully linked to the method of double taxation relief employed by a residence country. I argue that the uncertainty of the explanatory power of ownership efficiency, and the limits of current empirical understanding of the effects of alternative international tax policies, makes ownership neutrality an unreliable guide for policy prescription.

This Commentary next considers the effect of tracing indirect expenses, such as interest and general and administrative expense, and suggests this will result in an over-allocation of such expense to domestic income. I question whether it is desirable to further advantage foreign investment in light of the extent of questions regarding ownership neutrality as a policy guide. I then consider some of the "practical complications" briefly addressed by Hines, focusing on transfer pricing difficulties that make Hines' proposed exemption of foreign income (and the current system of deferral) problematic. This discussion supports evaluating policy changes at least in part on the basis of their expected effects on the business income tax base. The Commentary concludes with a brief consideration of Hines' comments on fairness.

\section{Ownership Neutrality and the Treatment of ForEIGN INCOME}

\section{A. The Importance of Ownership}

Hines places "the welfare impact of the importance of ownership to productivity" at the center of the welfare analysis of international tax rules." 12 Hines bases the importance of capital ownership, as opposed to the more traditional location of capital investment, on the "modern theory of foreign direct investment, which is based on a transactioncost approach under which the market advantages of multinational firms arise from the benefits of joint ownership of assets across locations." 13 Assets are owned by firms in part to overcome the limitations of alternative contractual ownership arrangements. While there is intuitive appeal to the notion that the right owner can wring more value from an asset than another owner, some of the premises of this analysis seem less than clear to a tax practitioner. What form of legal

12 Hines, note 1 , at 279.

13 Id. 
ownership of business assets does ownership neutrality require in order to achieve the efficiencies that Hines describes?

It is not clear which contract failures require a "firm's" ownership of assets ${ }^{14}$ and whether recent contract innovation overcomes these deficiencies. ${ }^{15}$ To a modern tax practitioner, there appear to be few limits to the ability to construct contractual arrangements to achieve tax and nontax outcomes. Some of Hines' prior work has focused on the trend away from joint venture arrangements in which control is shared with an unrelated party. ${ }^{16}$ The deconstruction of global business activity in the past decade, however, evidences that the ability to enter into a service or comparable contract outside of the control constraints of a joint venture is as viable a business strategy in most markets as operating a wholly-owned subsidiary. ${ }^{17}$ The contract limitation

14 Hines limits his discussion to business income and puts aside for later consideration the taxation of income of individuals and trusts. See id. at 269 n.1 Of course, individuals can earn business income both directly as proprietors and as members of partnerships carrying on business. While it might be that the reference to the "firm" is to an entity organized as a corporation, this does not seem necessary and would be placing great significance on the distinctions between the relevant corporate versus partnership, (disregarded) limited liability company or proprietorship doing business law. Presumably, Hines would extend his exemption prescription to a partnership and sole proprietor and not limit it to corporate income.

15 One possibility is that limits on the ability under contract to compel specific performance is a problem. The ability to terminate a contract and make a claim for money damages may be less robust as a source of compulsion than the ability to compel actions by employees (of the taxpayer or a subsidiary) through the threat of lower pay or dismissal.

16 Mihir A. Desai, C. Fritz Foley \& James R. Hines Jr., Costs of Shared Ownership: Evidence from International Joint Ventures, 73 J. Fin. Econ. 323 (2004) [hereinafter Joint Ventures]; Mihir A. Desai, C. Fritz Foley \& James R. Hines Jr., The Internal Markets of Multinational Firms, Surv. Current Bus., Mar. 2007, at 42.

17 See, e.g., Justin Scheck, Dell Plans To Sell Factories in Effort to Cut Costs, Wall St. J., Sept. 5, 2008, at A1 (reporting that Dell planned to sell all of its factories to contract manufacturers). As another example, recent ownership structures employed in China have expressly relied on so-called captive contractual arrangements with company founders as the sole source of ownership. These arrangements are designed with the implicit acquiescence of regulatory authorities to circumvent stock ownership limitations through use of contractual ties. The stock is marketed to the public as though these indirect ownership arrangements are the equivalent of direct ownership. Thus a VisionChina Media prospectus provides in part as follows:

Our advertising business is currently provided through our contractual arrangements with our consolidated affiliated entity in China, CDMTV. CDMTV is currently owned by Limin $\mathrm{Li}$ and Yanqing Liang and holds the requisite licenses to provide advertising services in China. CDMTV and its subsidiaries directly operate our advertising network, enter into direct investment and exclusive and non-exclusive advertising agency agreements, and sell advertising time to our clients. We have been and expect to continue to be dependent on CDMTV and its subsidiaries to operate our advertising business. We do not have any equity interest in CDMTV but receive the economic benefits of it through various contractual arrangements.

VisionChina Media Inc., Prospectus Form (424B4), at 24 (Dec. 6, 2007), available at http:// www.sec.gov/Archives/edgar/data/1415911/000119312507260361/d424b4.htm. 
argument also has been applied to valuable intangibles. ${ }^{18}$ The argument potentially has at least two elements, one suggesting that certain intangibles cannot be protected by contractual protections and the other suggesting that certain intangibles are not capable of being priced adequately on a royalty basis and therefore must be exploited by ownership. Again, anecdotal experience in the pharmaceutical industry suggests that economic returns from highly valuable intangible assets may be realized outside of exclusive ownership by a firm. ${ }^{19}$ These observations of market alternatives outside of traditional firm ownership controlling productive resources are evidence that there are varied modes of legal control of assets and resources. While taxation rules always will be a factor in the design of legal relations, it appears that resources may be employed and control maintained outside of traditional (exclusive) ownership by a firm. When these alternatives are taken into account, the linkage between exempting foreign income to avoid double taxation of foreign income and achieving optimal ownership, including for this purpose contractual arrangements with third parties that achieve control over productive resources equivalent to ownership, does not appear to be as strong as Hines would suggest.

Hines infers from the large and active worldwide market in mergers and acquisitions, that participating firms "assume the costs of ownership realignments because of their advantages."20 Experience of recent years raises questions whether evidence would support that mergers and acquisitions have enhanced efficiency, or whether agency problems (including misdirected executive compensation incentives) have promoted acquisitions that are suboptimal in outcome. It is possible that merger and acquisition activity in recent years, when leveraged buyouts benefiting from easy credit and low interest rates played an important role, was in part the product of a tax distortion favoring debt over equity in an environment when nonpublic private equity firms employed greater leverage and therefore bid higher prices than publicly traded owners and competing publicly traded strategic buyers. Merger and acquisition activity does not seem to be strong evidence for efficiency advantages of ownership realignment.

18 See Desai et al., Joint Ventures, note 16, at 341-45.

19 See, e.g., Press Release, AstraZeneca, AstraZeneca and AtheroGenics Announce Late Stage Licensing and Commercialization Agreement for Novel Atherosclerosis Drug AGI-1067 (Dec. 22, 2005), available at http://www.astrazeneca.com/media/latest-pressreleases/2005/5206?itemID $=3892375$ (stating that AtheroGenics would receive $\$ 50$ million up front and up to $\$ 1$ billion if milestones met).

20 Hines, note 1 , at 279 . 


\section{B. Ownership, Substitution, and Limited Financial Capital}

The centerpiece of Hines' criticism of the traditional locational neutrality analysis is the unrealistic assumption that foreign-owned U.S. investment would not replace U.S. capital invested abroad. ${ }^{21}$ This seems a fair criticism as a general matter, but, purely from a tax perspective, it is not clear that foreign and U.S. owners are perfect substitutes. Hines assumes that the United States can readily collect the same tax revenue from foreign-controlled firms as from U.S. firms. ${ }^{22}$ In such case, under Hines' ownership analysis, substitution of foreign for domestic ownership of an asset would add equally to U.S. tax revenue and there would be a gain in overall U.S. welfare from the increased return to the U.S. investor from owning the foreign asset. There is evidence to suggest that the United States does not collect the same taxes on foreign-controlled U.S. firms as on U.S.-controlled firms although the reasons for this are unclear. ${ }^{23}$ If the data is correct, U.S. and foreign ownership of the asset should not be viewed as perfect substitutes from the perspective of U.S. revenue.

In earlier work Mitchell Kane enumerated a series of questions regarding Hines' ownership neutrality, ${ }^{24}$ including an implicit assumption that investors have a finite amount of financial capital. Kane argues that a more realistic assumption is that a business firm has access to additional financial capital. ${ }^{25}$ If the latter assumption is correct, then there need not be a trade-off in relinquishing ownership of one asset in order to acquire another, if the acquirer issues stock for the new asset and retains ownership of its existing assets. Hines appears to respond by suggesting that expanding asset ownership by a single owner would itself be inefficient since single ownership is itself inefficient. ${ }^{26}$ Hines asserts that efficient ownership entails "combining assets in a way that is more productive than alternative ownership ar-

21 Id. at $280-81$.

22 Id. at 278.

23 See, e.g., GAO, Tax Administration: Comparison of the Reported Tax Liabilities of Foreign- and U.S.-Controlled Corporations, 1998-2005, at 3 (2008), available at http://www. gao.gov/new.items/d08957.pdf (noting that foreign-controlled domestic corporations reported lower tax liabilities than U.S.-controlled domestic corporations). The GAO does not reach a conclusion regarding the reason for its finding, observing that it could be attributable to the age and mix of foreign controlled businesses or it could be attributable to transfer pricing. Id. at 15 . The GAO analysis whether there is a specific tax reason (transfer pricing) for lower tax on foreign-owned U.S. investment faces the same practical difficulty of identifying causation as described below in relation to determining the effect of the method of double taxation relief on foreign direct investment.

24 Mitchell A. Kane, Ownership Neutrality, Ownership Distortions, and International Tax Welfare Benchmarks, 26 Va. Tax Rev. 53 (2006).

25 Id. at 75.

26 Hines, note 1 , at 276 . 
rangements." 27 If Hines is arguing that concentrated ownership of assets is inefficient, the basis for that conclusion is not articulated (and one would suspect that the premises of ownership neutrality would promote concentration of ownership). Why would General Electric necessarily be a less efficient owner of an asset than a smaller company? Even if Hines' apparent argument regarding single ownership is correct, however, Kane's observation regarding expanded U.S. ownership would not seem to require that there be a concentration of ownership. If ownership of the foreign asset does not require a change in ownership of existing assets, the force of the substitution argument as support for preferring ownership to locational neutrality would be diminished.

\section{Is There a Determinable Linkage Between Ownership and the Method of Double Taxation Relief?}

Assuming that multinational asset ownership has unique significance, what is the linkage to double tax relief by exemption rather than foreign tax credit? It is an empirical question whether welfare loss results if assets cannot be owned by a multinational resident in any country without suffering a different effective tax rate. ${ }^{28}$ Hines cites studies of the effects of taxation on the location of investment and the ownership structure of cross-border investment. ${ }^{29}$ Kane has questioned whether the empirical evidence Hines cites regarding the effect of tax distortions on investment is evidence of tax-induced ownership distortion or location distortion. ${ }^{30}$ Further, it is not possible to insulate the effects of every tax attribute on effective tax rates of different owners. Is allowing a multinational company to bid on or own assets in low-tax countries (or own an asset subject to a low effective tax rate as a result of tax planning) undisturbed by home country taxation a cure that is meaningfully related to suboptimal asset ownership? To arrive at an empirical answer to this question it would be necessary to identify effects on asset ownership of differences in taxation resulting from alternative methods of double taxation relief (taking account of contractual alternatives available to a firm in addition to a traditional joint venture) and estimate the welfare loss resulting from these differences.

27 Id.

28 Kane observes that the only relevant ownership distortions are those that affect differences in productivity derived from the asset. Kane, note 24, at 58-59.

29 Hines, note 1 , at $279-80$.

30 Kane, note 24 , at $60-67$. 


\section{Neutrality and International Tax Policy}

The Report of the American Bar Association Tax Section Task Force on International Tax Reform reviewed the various normative criteria proposed to evaluate the efficiency of alternative international tax policies, including capital export neutrality, capital import neutrality, national neutrality, capital ownership neutrality, and national ownership neutrality. ${ }^{31}$ The report concluded that there was not sufficient evidence to reach a consensus that any of the competing neutrality standards provided sufficient certainty regarding U.S. welfare gains or losses to be determinative in the design of the international tax rules. ${ }^{32}$ Harry Grubert and Roseanne Altshuler have come to a similar conclusion on the basis that there simply is not an ability under current knowledge to determine the welfare effects of alternative benchmarks. ${ }^{33}$ Before turning to "complications," I first consider the consequences of Hines addition of tracing of indirect expenses to his exemption prescription.

\section{Exemption of Foreign Income Without Allocation of INDIRECT EXPENSES}

\section{A. The "Folly" of Tracing Interest Expense}

Hines argues that to assure ownership neutrality, general business deductions such as interest and general and administrative expense should not be allocated between domestic and foreign income, but

31 ABA, Tax Section, Report of the Task Force on International Tax Reform, 59 Tax Law. 649, 660-61, 680-89 (2006).

32 Id. at 661.

${ }^{33}$ Harry Grubert \& Rosanne Altshuler, Corporate Taxes in the World Economy: Reforming the Taxation of Cross-Border Income, in Fundamental Tax Reform: Issues, Choices and Implications 319 (John W. Diamond \& George R. Zodrow eds., 2008). Grubert and Altshuler state:

One of the difficulties in evaluating reform proposals is that the models and estimates of behavioral elasticities required for judging an international tax system definitively are beyond the scope of current knowledge and we cannot assume that they will ultimately be knowable. There is an extensive literature on the alternative principles that should guide the process, including Capital Export Neutrality (CEN), Capital Import Neutrality (CIN), and more recently, Capital Ownership Neutrality (CON). However, none of these benchmarks is satisfactory because the argument supporting them usually takes place within very simple models. The necessity to examine all the important responses to a change in the tax on international corporate income such as the choice of where to exploit intangible assets like patents, the choice of where to locate income and expenses for tax purposes, and the choice between alternative types of financing in different locations, among other decision margins, makes it clear that no one-dimensional criterion is useful and that a complete evaluation of any reform proposal is probably not feasible.

Id. at 320 . 
should be traced directly to their uses. ${ }^{34}$ Tracing effectively will result in over-allocation of expense to domestic income. Practical experience endorses the observations of Michael Graetz, who writes: "Given the fungibility of money, knowing the purpose of borrowing is an impossible quest"; he refers to "the folly of attempting to trace borrowed money to its use." 35 The same difficulties apply to general and administrative expense that is not susceptible of direct allocation.

\section{B. Stakes ${ }^{36}$}

Allowance of a deduction against domestic income to earn exempt foreign income results in a permanent revenue loss equal to the tax saved from the amount expensed. If the tax rate is $35 \%$, deducting an expense of $\$ 100$ results in saved tax of $\$ 35$.

Example 1: Assume U.S. Multinational (USM) has a marginal effective tax rate of $35 \%$ on its U.S. income and a marginal effective tax rate of $10 \%$ on income earned in Country $X$ by a foreign affiliate, $F$ Sub. USM incurs $\$ 100$ of interest on U.S. borrowing and general and administrative expense. Country $X$ does not allow $F S u b$ to deduct a cost reimbursement paid to $U S M$ in relation to the G\&A expense and does not allow a deduction for interest on U.S. debt. As a result, $F$ Sub pays a $10 \%$ tax on income that otherwise would have been deducted.

If the United States exempts $F$ Sub's income, allowing the deduction provides a $35 \%$ benefit in addition to the exemption of the income that is taxed at a $10 \%$ rate by Country $X$. In other words, allowing the deduction creates a negative tax on (that is, subsidizes) the exempt foreign income. ${ }^{37}$ Allowing a deduction for interest without allocation of interest expense to foreign income cannot be justi-

\footnotetext{
34 Hines, note 1 , at 283 .
}

35 Michael J. Graetz, A Multilateral Solution for the Income Tax Treatment of Interest Expenses, 62 Bull. Int'l Tax'n 486, 489 (2008).

36 The discussion in this Section draws on testimony given before the Senate Finance Committee. See The Foundation of International Tax Reform: Worldwide, Territorial, and Something in Between, Hearing Before the S. Comm. on Finance, 110th Cong. (2008) (statement of Stephen E. Shay, Partner, Ropes \& Gray LLP) [hereinafter Shay Statement].

37 Graetz, note 35, at 491 ("[A]llowing a deduction in a higher-tax country for borrowing to invest in a lower-tax country can produce after-tax returns greater than the investment's pre-tax returns. This means that investments that would not be undertaken by anyone in a world without any corporate income taxes may become attractive in a world with varying tax rates and no interest allocation. Such investments will clearly decrease worldwide welfare and will, almost certainly, decrease welfare in the countries where the interest deductions are allowed."). 
fied on any neutrality ground. ${ }^{38}$ Moreover, to the extent that exemption is not justified on welfare grounds, misallocation of deductions exacerbates the welfare loss.

The argument is made, however, that if a deduction for interest, stewardship, or other indirect expense is not allowed as a deduction by the country of residence of the investor, and the source country does not allow the deduction, the resulting "double taxation" will penalize foreign investment. If the source country does not accept that an amount of interest or stewardship expense should be deducted as a cost of earning source country income, under what principle should the residence country be required to alleviate the source country taxation by allowing the deduction from gross income that the residence country does not include in its tax base, and, if it did, would have offset with an interest deduction? As discussed above, this would go beyond avoiding double taxation as a rationale for exemption of foreign income; it would subsidize earning foreign income. The welfare benefits of ownership neutrality, if any, would appear to be too speculative to justify the potentially substantive loss of the residence country revenue base.

IV. "Complications": Transfer Pricing and Exemption of Foreign INCOME ${ }^{39}$

In arguing that exemption of foreign income maximizes national welfare, Hines notes "the requirement that taxpayers adhere to rules concerning the allocation of income for tax purposes." 40 Yet, Hines also "follows almost all of the preceding literature in taking enforcement matters to be outside the scope of the present inquiry . . . ."41

The scale of the enforcement difficulty in relation to transfer pricing and allocation of deductions is substantial and is exacerbated as tax rate differentials increase. The benefits (or detriments) of a misallocation of income or a deduction recognized by both countries is measured by the difference in tax that results from the improperly allocated income or deduction.

38 Id. ("Empirical evidence about the benefits that might justify such a policy does not exist, nor does it seem likely that any evidence will be forthcoming that would justify such negative taxes as standard policy. A far better policy... would be for all countries to allow interest deductions on borrowing in proportion to the assets in that country regardless of where the borrowing takes place.").

39 The discussion in this Section also draws on testimony given before the Senate Finance Committee. See Shay Statement, note 36.

40 Hines, note 1, at 278.

41 Id. at 296. 
Example 2: If U.S. Multinational (USM) has a marginal effective tax rate of $35 \%$ on its U.S. income and a marginal effective tax rate of $10 \%$ on income earned in Country $X$ by a foreign affiliate, $F S u b$, the tax benefit of allocating income from $U S M$ to $F S u b$ would be a tax saving of $25 \%$ of the amount of income transferred.

With exemption of foreign income, the benefit is permanent. There is consistent evidence that flexible transfer pricing standards and weak .or nonexistent enforcement is contributing to significant income shifting to lower-tax jurisdictions. ${ }^{42}$ The following discussion explains why "strict adherence" to transfer pricing standards is extremely difficult to enforce in the face of material differences in effective tax rates.

\section{A. Information Asymmetry and the Limits on Transfer Pricing Enforcement}

Transfer pricing is difficult for any government to administer and enforce. At the heart of the problem is that transfer pricing issues are intensely factual and the taxpayer possesses the relevant facts. There is an unavoidable uncertainty in the application of the arm's length standard for both the taxpayer and the government. Transfer pricing is particularly difficult for income from intangible property and highvalue services. In this context, where comparable transactions are not readily available to benchmark an arm's length price, the practical hurdles to government enforcement are magnified. The difficulties with administering transfer pricing rules where comparable third party transactions are unavailable or inexact include: (1) the necessary flexibility of the transfer pricing rules to allow taxpayers to structure their affairs (as well as an arguably excessive electivity of methods), ${ }^{43}$ (2) the operational flexibility available to a multinational in planning and executing a transfer pricing strategy, ${ }^{44}$ and (3) the taxpayer's advan-

42 See, e.g, Michael McDonald, Income Shifting from Transfer Pricing: Further Evidence from Tax Return Data (U.S. Treas. Dep't OTA Paper No. 2, 2008), available at http:/ /www.treasury.gov/offices/tax-policy/library/DTAtech02.pdf; GAO, Multinational Corporations: Effective Tax Rates Are Correlated with Where Income Is Reported (2008), available at http://www.gao.gov/new.items/d08950/pdf; U.S. Treas. Dep't, Report to the Congress on Earnings Stripping, Transfer Pricing and U.S. Income Tax Treaties 58 (2007), available at http://www.treas.gov/offices/tax-policy/library/AJCA2007.pdf (noting a correlation between reductions in foreign effective tax rates of controlled foreign corporations and income shifting from high nominal tax rate countries to low-tax rate countries).

43 The $\S 482$ regulations treat results within a defined range as "arm's length" and not subject to adjustment. See Reg. $\S 1.482-1(\mathrm{e})(1)$. This is only one element of the regulations' flexibility.

44 See Ilan Benshalom, Sourcing the "Unsourceable": The Cost Sharing Regulations and the Sourcing of Affiliated Intangible-Related Transactions, $26 \mathrm{Va}$. Tax Rev. 631, 646-47 
tages from information asymmetry and procedural electivity in documenting transfer pricing and defending transfer pricing controversies.

A government trying to evaluate a taxpayer's transfer pricing decision faces a steep information deficit. ${ }^{45}$ Taxpayers need not routinely disclose relevant facts on either tax returns or consolidated financial statements. ${ }^{46}$ If the government performs an audit, it must ask the right questions in order to elicit information relevant to a pricing analysis. The examining agents must learn enough about the business and its economics to determine when income and margin are out of line. Well-advised and disciplined taxpayers prepare their cases as soon as the audit starts (in addition to prior planning for these issues) and know where the sensitivities lie. While a taxpayer must answer truthfully and fully an information document request (IDR), they have no obligation to direct the government to the right question or data absent an IDR request. Even for large taxpayers subject to continuous audit, there is a material risk of nondetection of a broad range of inappropriate transfer pricing.

Assuming that a transfer pricing issue is properly identified and sufficient information is developed for the Service to make a proposed adjustment, a taxpayer often can persuade a reviewer (an appellate conferee or trial counsel) that the government has sufficient "hazards of litigation" that the taxpayer's allocation would be sustained (even with the burden falling to the taxpayer to demonstrate that the government's proposed allocation is unreasonable and the taxpayer's allocation is reasonable) to achieve a compromise at less (and often substantially less) than a $100 \%$ taxpayer concession. ${ }^{47}$ Moreover, unless the taxpayer's conduct is egregious, if the Service does persuade a trier of fact that the Service adjustment should be sustained, it is difficult for the Service to effectively impose a transfer pricing penalty

(2007) ("[The] characteristics [of arm's length transfer pricing] render futile the attempt of the transfer pricing rules to determine the reasonable price at which affiliated transactions would have been valued if made with unrelated parties.").

45 See id. at 647 . The problem of information asymmetry is especially acute in the case of the allocation of expenses. It is extremely difficult for the government to readily identify how expenses should be allocated to a category of income or activity.

46 There is reporting of related party amounts under $\S 6038$, but these reports do not highlight when the pricing may be inconsistent with the arm's length standard. Although many taxpayers with large intercompany payments usually prepare $\S 6662$ transfer pricing documentation as a defense against penalties, it is designed to demonstrate the reasonableness of the taxpayer's method without highlighting whether it involves a major exposure. It remains unclear whether and how the relatively new FIN 48 financial standards will affect this calculus. Fin. Accounting Standards Bd., FASB Interpretation No. 48: Accounting for Uncertainty in Income Taxes (2006), available at http://www.fasb.org/pdf/fin\% 2048.pdf.

47 Too often, the Service proposes an adjustment that loses credibility with the trier of fact (whether an appellate conferee or a judge) that they do not recover during the case. 
(and is particularly difficult in the context of settling a controversy). In the face of such difficulties and the large expense to the government of trying a case, settlements are common and necessary to allow the tax enforcement system to function. While there are (relatively rare) transfer pricing controversies where penalties are applied, the penalty structure generally is not sufficient to create a taxpayer disincentive to taking advantage of the preceding difficulties in enforcement (and it is unlikely that such a penalty system could be adopted). ${ }^{48}$

These features of transfer pricing make it rational for a taxpayer to take positions that are aggressive. To fail to do so is to leave a tax decisionmaker open to criticism that the tax planning has "left money on the table." The extent to which a taxpayer pushes its transfer pricing to the limit of an arm's length range is largely a function of its appetite for tax risk and whether the taxpayer (in particular a public company) can persuade its auditors that either it is not necessary to establish a reserve or that a modest reserve is sufficient. None of the preceding discussion is intended to refer to tax positions that are not fully justified from a legal and ethical perspective. Indeed, that is the point. ${ }^{49}$ The data evidence the outcome of these structural incentives. $^{50}$ In light of the incentives to shift profits where there is the potential to achieve materially lower effective tax rates, the limits on the ability to enforce transfer pricing require that it be taken into account in designing our international rules.

While it is important to improve our substantive transfer pricing rules and to create procedural disincentives for aggressive transfer pricing, it is unrealistic to believe that this will do more than mitigate the inherent flexibility to adjust transfer prices. Nor is formulary apportionment-a method that, based on several inputs such as allocation of property, wages, and sales, will determine how income is split by formula-a viable alternative to the arm's length method of current law. If, as is the case under U.S. state formula apportionment methods, income allocated under a formula apportionment method to another taxing jurisdiction is exempted by the jurisdiction applying the formula apportionment method, tax rate differentials will continue

48 See generally Kyle D. Logue, Optimal Tax Compliance and Penalties When the Law is Uncertain, 27 Va. Tax Rev. 241 (2007) (discussing optimal penalty structures).

49 See Yariv Brauner, Value in the Eye of the Beholder: The Valuation of Intangibles for Transfer Pricing Purposes, 28 Va. Tax Rev. 79, 157 (2008) ("The claim of this article is that at each decision level the law permits almost frictionless flexibility to taxpayers.")

50 See studies cited in note 42; see also Martin A. Sullivan, Multinationals Shifting Profits Out of the United States, 118 Tax Notes 1078 (Mar. 10, 2008); Martin A. Sullivan, Extraordinary Profitability in Low-Tax Countries, 120 Tax Notes 724 (Aug. 25, 2008). 
to exist. ${ }^{51}$ If present effective tax rate differentials remain unchanged, the taxpayer advantages described above also will allow taxpayers to manipulate the factors underlying formula apportionment to the same or a greater extent as under the arm's length separate transaction method. ${ }^{52}$ The implication of the preceding analysis is that, in the face of the inherent limits on the ability of a government to monitor and enforce any transfer pricing regime, it is important that there be structural limits on the ability of taxpayers to take advantage of effective tax rate differences in implementing transfer pricing within a controlled group.

\section{A Brief Note on Fairness}

Hines addresses potential objections that exemption of foreign income raises fairness concerns. To set up the issues, Hines hypothesizes two taxpayers each of whom earn $\$ 100$ of income. One taxpayer with $\$ 100$ of domestic income is taxed at $35 \%$ and a second taxpayer with $\$ 100$ of foreign income is not taxed on the income in the source or residence country. Hines observes that such an outcome could be viewed as unfairly burdening the taxpayer paying tax on domestic income, but, he argues, on closer examination the fairness concern is not warranted. 53

Hines first observes that the pretax position of the taxpayers are different. The taxpayer earning the foreign income must operate in the face of competitors not subject to the same home country tax regime or firms from the source country. If these firms' profits are not taxed, competition would be expected to cause returns to decline to equal after-tax returns available elsewhere. In other words, the investor in a low-tax country "pays an implicit tax in the form of lower returns produced by market competition." 54

51 It is possible that under formulary apportionment methods, income (particularly from intangibles) would be allocated away from low-tax countries where little economic activity involving property, payroll, or sales takes place. That will depend, of course, on the specifics of the rules adopted. Experience at the level of U.S. states suggests that these rules remain subject to manipulation.

52 Moreover, in order for a formula apportionment regime to work, the several taxing jurisdictions would have to have sufficiently similar income allocation formulas so that the income apportioned by the residence state to the other state bears some resemblance to the income actually taxed by the other state. Otherwise there will be substantial risk of double taxation and double nontaxation in everyday business transactions that today are handled adequately under the arm's length, separate transaction method that currently benefits from a broad international consensus. It might be possible to develop a new international transfer pricing consensus around a common formulary apportionment method that could be adopted on a global basis. This likely would take a decade or more with no assurance of a successful outcome.

53 Hines, note 1, at 292.

54 Id. at 293. 
Hines notes that commentators, including my co-authors Clifton Fleming and Robert Peroni and I, have objected to this line of justification on the grounds that implicit taxes are not paid to governments and are not normally considered the subject of double taxation relief. ${ }^{55}$ Hines notes the "intrinsic vagueness of almost any notion of fairness" but nonetheless argues from the "standpoint of the ultimate distribution of income, the question remains whether an investor who has already paid an implicit tax needs to be subject to an explicit home country tax in the name of fairness." 56 It is not clear what Hines refers to by "ultimate distribution of income." 57 The reference is not developed and standing alone is too imprecise to know whether it is intended to relate to tax burden in relation to income distribution-a controversial topic in and of itself. ${ }^{58}$ Nor does it appear that Hines is seriously suggesting that implicit taxes could be taken into account in a distributional analysis as a practical matter. I interpret Hines' fairness comments to be more in the nature of an objection that assertions of fairness do not have sufficient grounding in economic distributive justice principles to be given weight (at least with respect to international income). The difficulty with this position is that elected policymakers place material weight on fairness concerns and, difficult as they may be, they need to be analyzed and addressed. ${ }^{59}$ It is difficult to reconcile tax advantages for foreign investment that exceed what is needed to avoid double taxation of income with traditional ability-to-pay fairness standards. Additional evidence would be needed in support of the efficiency claims for ownership neutrality and in the linkage between advantaging foreign income and ownership to overcome the fairness concerns with subsidizing foreign investment.

55 Id. (citing J. Clifton Fleming, Jr., Robert J. Peroni \& Stephen E. Shay, Fairness in International Taxation: The Ability-to-Pay Case for Taxing Worldwide Income, 5 Fla. Tax Rev. 299, 317-18 (2001)).

56 Hines, note 1 , at 293 . Hines also questions why a similar fairness argument is not made for subjecting foreign value added to domestic value-added taxation on the basis that the effect of a residence-based excise or value-added taxation on ownership is the same as an income tax. Id. at 58-59. I do not take up Hines' indirect tax arguments in this Commentary.

57 Fairness is indeed a difficult standard to pin down. My co-authors and I have made explicit the reasons we utilize an "ability-to-pay" standard, including that it appears to be the prevailing measure used by policymakers. Fleming et al., note 55, at 301-14. We explicitly acknowledge that dissenters from this consensus could allocate the tax burden on a different basis. Id. at 309.

58 See, e.g., Lawrence Zelenak, Framing the Distributional Effects of the Bush Tax Cuts, 105 Tax Notes 83 (Oct. 4, 2004).

59 See Fleming et al., note 55, at 301-06; Michael J. Graetz, Taxing International Income: Inadequate Principles, Outdated Concepts and Unsatisfactory Policies, The David R. Tillinghast Lecture, NYU School of Law (Oct. 26, 2000), in 54 Tax L. Rev. 261, 294, 307 (2001). 


\section{Conclusion}

Hines, and his frequent co-author Mihir Desai, have by criticizing traditional neutrality standards and introducing ownership neutrality to the debate, advanced the discussion of neutrality norms in relation to international income. Nonetheless, Hines has not surmounted continued questions regarding the explanatory power of ownership efficiency and does not directly address whether developments in the marketplace call into question looking to ownership neutrality as a policy guide. In this context, failing to allocate deductions to foreign income seems particularly risky. Moreover, the complications of transfer pricing and size of income shifting even under today's deferral regime suggest that these are considerations that cannot be ignored in prescribing exemption of foreign income. 